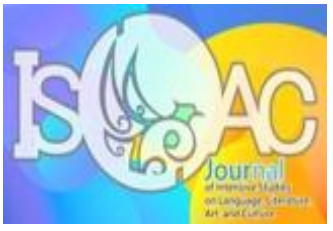

ISLLAC : Journal of Intensive Studies on Language,

Literature, Art, and Culture

Volume 2 Issue 2, 2018

Journal homepage :

http://journal2.um.ac.id/index.php/jisllac

\title{
THE APPLICATION OF STUDENT CENTERED LEARNING THROUGH LESSON STUDY ON QUALITY AND LEARNING RESULTS
}

\author{
Sigit Dwi Saputro* \\ (Dosen di Prodi Pendidikan Informatika, Fakultas Ilmu Pendidikan, Universitas Trunojoyo Madura)
}

\begin{tabular}{|c|c|}
\hline A R T I C L E I N F O & A B S T R A C T \\
\hline $\begin{array}{l}\text { Keyword: } \\
\text { Student-Centered Learning, } \\
\text { Lesson Study, } \\
\text { Learning Quality and } \\
\text { Learning Outcomes }\end{array}$ & $\begin{array}{l}\text { This study aims to determine the quality and effectiveness of student learning } \\
\text { outcomes after the student-centered learning approach is applied through lesson } \\
\text { study. The subjects in this study were students of the Informatics Education Study } \\
\text { Program at the Faculty of Education, the University of Trunojoyo Madura in the } \\
\text { fourth semester in material Elektronik, Analog dan Digital. Data collection techniques } \\
\text { through documentation, observation, and tests. The results were: 1) provide leadership } \\
\text { skills, time management, empathy, communication focus, and learning activities, 2) } \\
\text { find out the best ways to optimize student learning quality, 3) There were influence } \\
\text { learning outcomes. }\end{array}$ \\
\hline
\end{tabular}

\section{INTRODUCTIONS}

Undang-Undang Republik Indonesia number 20 of 2003 concerning the Education System in Chapter III article 4 paragraph (3) contains provisions regarding the implementation of education, as follows: "Education is held as a process of civilizing and empowering students that lasts for life". Furthermore, in Article 4 paragraph (4) there are provisions as follows: "Education is held by giving exemplary, building willingness, and developing students' creativity in the learning process"

Based on these regulations, as an educator in universities, it is necessary to pay attention to the empowerment process of students in each lecture activity. One model that empowers student activities in learning is student-centered learning (SCL). SCL has a constructivist rationale with emphasis on students as the centered of learning process activities (Triyono, 2011).

Whereas according to Afiatin (2005: 1), he explained the application of the SCL method also applied learning based on mastery of the material level. In the SCL method, students get the opportunity and facilities to build their own knowledge so that they will gain deep learning and ultimately improve the quality of students. Operationally, in SCL the students have the freedom to develop all their potential (creativity, feeling, and intention), explore the fields/knowledge that they are interested in responsibly, build knowledge and then achieve their competence through active, interactive, collaborative learning processes. Cooperative, contextual and independent.

Students are in the centered of the learning process; while the teacher encourages them to be responsible for their own learning. With this concept, requires teachers to design learning activities where students have greater responsibility for their own learning and interact with others Jacobsen (2009: 228)

SCL has four benefits according to Priyatmojo (2010), namely: 1. Developing thinking ability by exchanging ideas between students. 2. The development of a sense of tolerance, empathy, sympathy, and respect for the opinions of others. 3. Increased knowledge, because of the opportunity to get and receive information from each other 4 . There is new knowledge for students who provide information.

\footnotetext{
${ }^{*}$ Corresponding author.

E-mail addresses: sigitd.saputra@trunojoyo.ac.id (Sigit Dwi Saputro)
}

ISSN : 2597-7385 (Online) - ISLLAC : Journal of Intensive Studies on Language, Literature, Art, and Culture is licensed under Creative Commons Attribution-ShareAlike 4.0 International License (http://creativecommons.org/licenses/BY/4.0/). 
In order for SCL to run optimally, it is necessary to pay attention to several terms and conditions (Priyatmojo, 2010). These conditions are 1. Heterogeneous grouping of students, for example, knowledge, analytical skills, and ethnic differences 2. Tasks and learning structures must be explained in detail 3 . Students already have learning experience 4. Provided access to contribute/to speak fairly 5. Each student contributes their opinions 6 . Students are able to explain the reasons for their opinions 7 . Students want to listen and comment on their friends' opinions. 8. The results of the discussion are "lists of opinions or ideas" that are accepted by all group members 9. The learning process must be supported by an atmosphere of mutual understanding.

The learning design used is Lesson Study. According to (1) (Hurd, Jacqueline; Licciardo-Muso 2005), Lesson study is not a new program but aims to help educators to streamline their own learning methods.

According to (Sibbalad TEAM 2009) and (Lomibao 2016) lesson study can improve student learning outcomes. In addition to lesson learning outcomes, studies can also improve creative thinking needs (Nuha 2018). Benefits that can be obtained from the application of Lesson study with the presence of our observers find the best ways students learn. Group formation can develop leadership skills, time management, empathy, and communication and moderation focus (Histor 2018).

Based on several theories and research results that have been described, it is necessary to conduct a study with the theme of the Application of Study Lesson with the Student-Centered Learning Model to determine the quality and learning outcomes of students.

\section{METHOD}

The subjects in this study were students of the Informatics Education Study Program at the Faculty of Education, the University of Trunojoyo Madura in the fourth semester who took Analog and Digital Electronics courses. The number of students in the study consisted of 31 people joined in one class, namely class $4 \mathrm{~A}$.

The study was conducted in September to October 2018, in the Informatics Education Study Program, Faculty of Education, University of Trunojoyo Madura.

The research applied using the lesson study approach with the steps of learning activities includes 1) Has the material: and learning objectives based on curriculum and student characteristics to fit the learning objectives, 2) Planning: contains the selection of learning models that are using the studentcentered by preparing data collection instruments, 3) Conducting research: one team doing learning and gathering data, 4) reflection: what learning is gained after students learn in class and the implications for more profound improvement (Hurd, Jacqueline; Licciardo-Muso 2005). The learning activities can be specified as table 1.1 (3)

Table 1.1 lesson study learning plans for electro analog and digital courses.

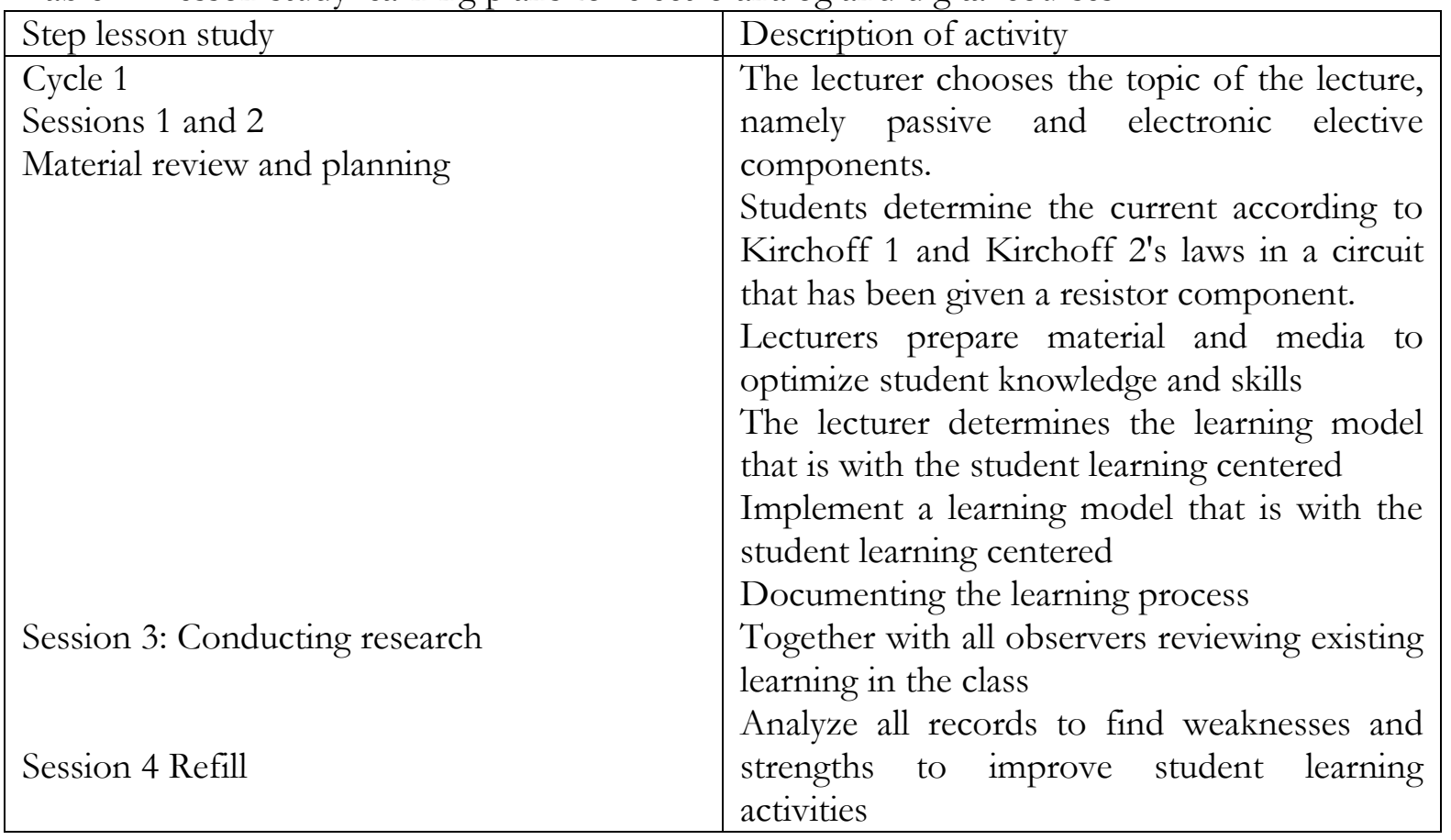




\begin{tabular}{|c|c|}
\hline Step lesson study & Description of activity \\
\hline $\begin{array}{l}\text { Cycle } 2 \\
\text { Sessions } 1 \text { and } 2 \\
\text { Material review and planning }\end{array}$ & $\begin{array}{l}\text { Lecturers make revisions to learning } \\
\text { improvements based on notes of reflection } \\
\text { on cycle } 1 . \\
\text { The lecturer continues the learning topic } \\
\text { namely binner numbers. } \\
\text { Students can change the decimal number to } \\
\text { binner, binner to decimal, add and multiply } \\
\text { binary numbers. } \\
\text { Lecturers prepare material and media to } \\
\text { optimize student knowledge and skills }\end{array}$ \\
\hline & $\begin{array}{l}\text { Implement the learning model that is with the } \\
\text { student learning centered by paying attention } \\
\text { to the reflection notes on cycle } 1\end{array}$ \\
\hline Session 3: Conducting research & $\begin{array}{l}\text { Documenting the learning process } \\
\text { Together with all observers reviewing existing } \\
\text { learning in the class }\end{array}$ \\
\hline Session 4 Refill & $\begin{array}{l}\text { Analyze all records to find weaknesses and } \\
\text { strengths to improve student learning } \\
\text { activities }\end{array}$ \\
\hline Evaluation & $\begin{array}{l}\text { Measuring student understanding through } \\
\text { cognitive tests }\end{array}$ \\
\hline
\end{tabular}

Modifications (Lomibao 2016) and (Hurd, Jacqueline; Licciardo-Muso 2005)

Data and techniques for collecting data from the beginning to the end of this study can be detailed as follows:

a. The situation of implementing lesson study with student-centered learning models was obtained through documentation techniques. The data presented are the learning process to determine leadership skills, time management, empathy, communication focus, active and contextual (Histor 2018) and Tina Afiatin (2005: 1).

b. Reflection of cycle 1 and Cycle 2 in learning activities through observation techniques

c. Student Learning Outcomes are obtained through tests, to find out the completeness of student learning, as a supporter to obtain an overview of student achievement after applying lesson study with the student learning model.

\section{FINDINGS AND DISCUSSIONS}

Findings

The results of the research that have been carried out include the presentation of documentation of data, observations and cognitive tests of analog and digital electronics as follows.

Based on the documentation of the Lesson Study learning activities with the Student-Centered Learning Model covering leadership skills, time management, empathy, communication focus, learning activities.

Students when given assignments for towards the discussion in one group to complete the task that has been given. Documentation results can be indicated by the initiation of ideas that appear in each group member. The existence of idea initiation is the initial leadership skill that grows as a result of the learning process as illustrated. 


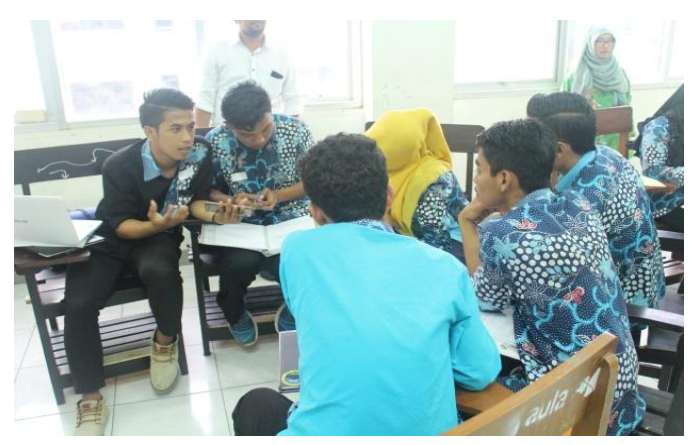

Figure 1.1 students submit ideas initiation.

When completing assignments students carry out the process of division of tasks in order to complete the task in accordance with the time limit that has been given. The division of tasks is the management of the team as shown in Figure 1.2

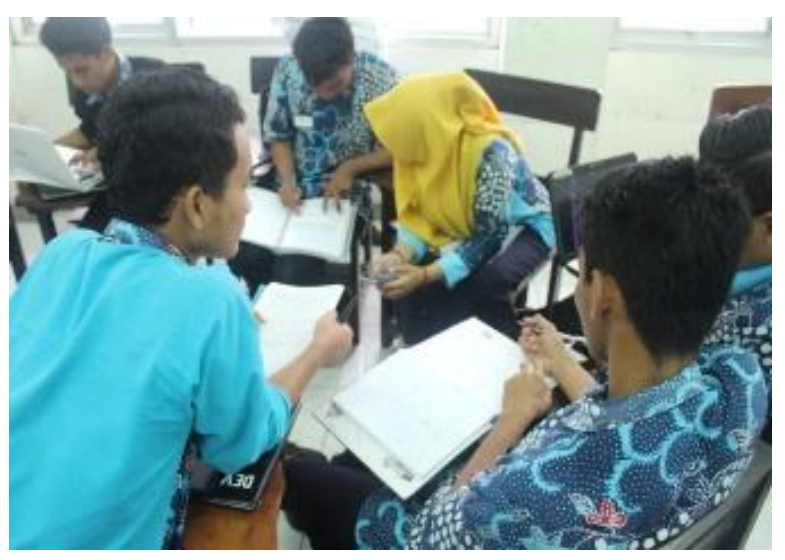

Figure 1.2 Division of tasks in solving problems.

Empathy also grows, namely the presence of each student listening or (not discussing themselves) when another group presents the results of their work with the aim of matching the results of the work of the group itself. Having respect for other groups by paying attention and listening carefully is one of the characteristics of empathy as shown in Figure 1.3.

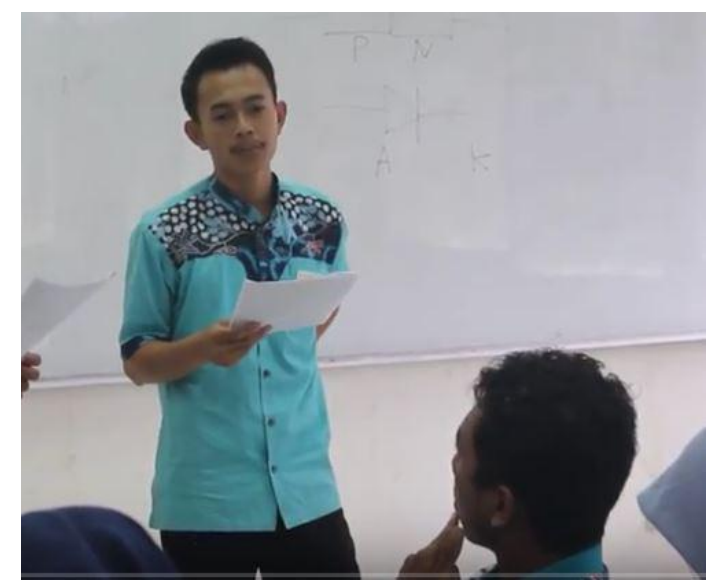

Figure 1.3 students listen when other groups deliver the results of the discussion

Giving assignments and groups has an impact on student communication patterns. The delivery of ideas and opinions to other friends is a matter of communication as shown in Figure 1.4. 


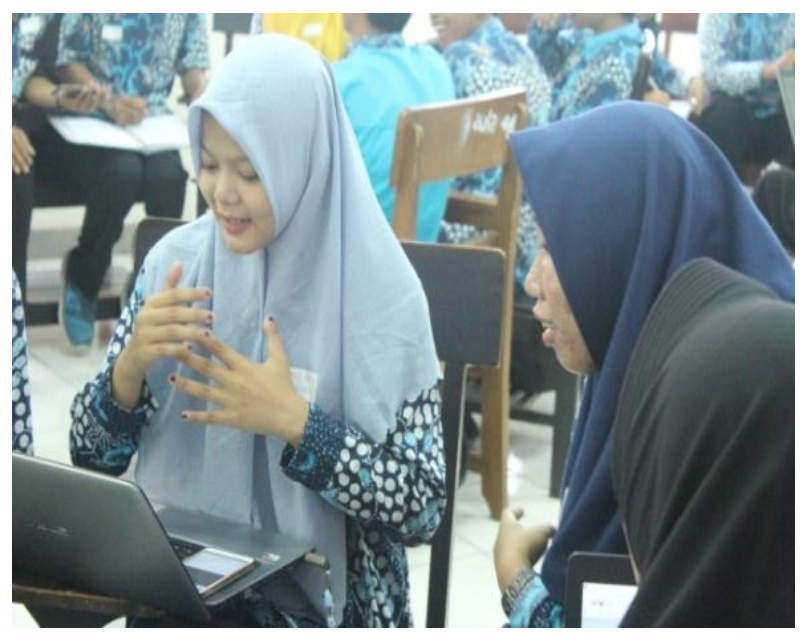

Figure 1.4 students communicate ideas in one group

Giving assignments and groups has the effect that students actively want to explain the assignments given and even look for other media sources and there are also those that compare the calculations with the system manually. The process of finding answers from various sources and comparing answers is student learning activities as shown in Figure 1.5

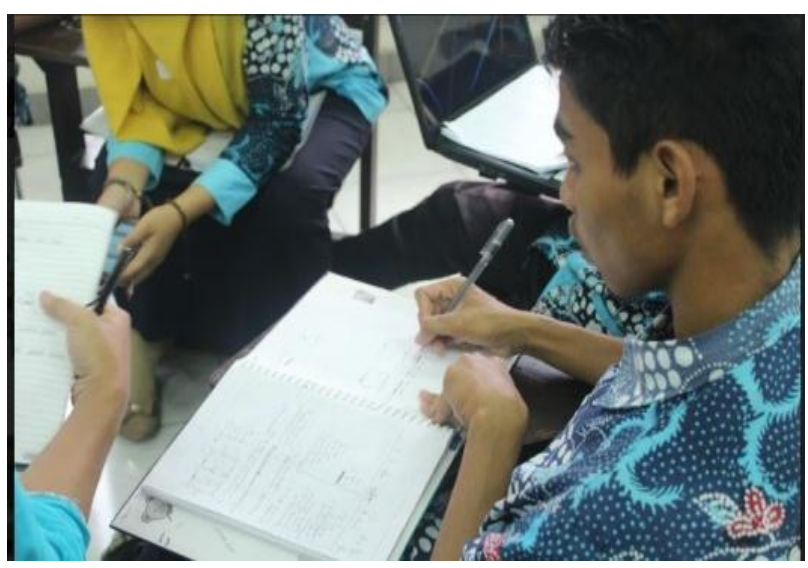

Figure 1.4 students compare findings with theoretical calculations.

The results of the observation are to obtain all the records to find the weaknesses and strengths of the learning process during reflection cycle 1 and cycle 2 with the Observer. The summary of the observations is summarized in table 1.2.

Table 1.2 results of reflection cycle 1 and cycle 2 .

\begin{tabular}{|l|l|}
\hline Observation & Reflection Results \\
\hline Cycle 1 & Deficiency \\
1. When there is a problem, immediately ask the Lecturer \\
2. There is no communication between students at each point \\
with the other end \\
3. Fear of asking other friends \\
Advantages \\
$\begin{array}{ll}\text { 1. The position of the seat in the middle is easier to understand } \\
\text { 2. Students actively collaborate } \\
\text { 3. Active students to exchange ideas and opinions } \\
\text { 4. Students look for other sources of information through the } \\
\text { internet } \\
\text { 5. In one group the students help each other when there are } \\
\text { problems. } \\
\text { Recommendations for improving the quality of learning }\end{array}$ \\
\hline
\end{tabular}




\begin{tabular}{|c|c|}
\hline Observation & Reflection Results \\
\hline & $\begin{array}{l}\text { Chair design as a place for discussion in completing learning } \\
\text { tasks must reach all students to be able to interact. }\end{array}$ \\
\hline Cycle 2 & $\begin{array}{l}\text { Deficiency } \\
\text { 1. Students are less interested in answering the quiz given by the } \\
\text { lecturer. } \\
\text { Advantages } \\
\text { 1. Students actively cooperate } \\
\text { 2. Active students to exchange ideas and opinions } \\
\text { 3. Students look for other sources of information through the } \\
\text { internet } \\
\text { 4. In one group of students help each other when there are } \\
\text { problems. } \\
\text { Recommendations for improving the quality of learning } \\
\text { In order for students to have the spirit of answering quizzes, it } \\
\text { is necessary to create inter-group competitions and be given } \\
\text { rewards in the form of scores and awards for groups that are } \\
\text { able to answer correctly }\end{array}$ \\
\hline
\end{tabular}

The results of learning achievement are obtained through cognitive tests. Cognitive test results as an illustration of student achievement. The student learning outcomes are summarized as Table 1.3.

Table 1.3 Summary of Cognitive Test Results

\begin{tabular}{|l|l|}
\hline \multicolumn{2}{|l|}{ Cognitive Test Results } \\
\hline Average Value & 88.7 \\
\hline Pass & 28 \\
\hline Not Pass & 3 \\
\hline
\end{tabular}

Based on 1.3 it can be shown that the number of students in one class is 31 , while the average value is 88.7 students whose values exceed the KKM average (70) as many as 28 and less than KKM are 3. Classical completeness of students in Cycle 1 is 28/31 X 100\% $=0.9 \times 100 \%=90 \%$. Thus students in learning can meet the specified KKM standard, which is 70 with $90 \%$ classical completeness (capable of exceeding 75\%). The completeness can be seen in Figure.

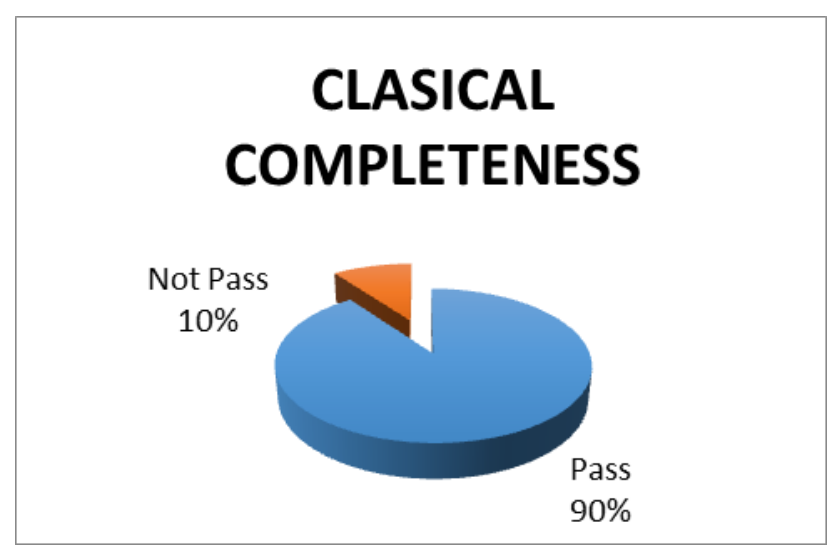




\section{Discussions}

Based on student documentation data shows 1) The attitude of leadership skills indirectly growing when the assignment is given by the lecturer, this growth is the initiation of an idea from each group member to exchange ideas in completing the task. 2) Team management is very visible with the division of tasks from individual students in completing assignments 3) Empathy also grows, namely the presence of each student listening or (not discussing themselves) when other groups present their work with the aim of matching the results of their own group work. 4) Communication focus, in one group intense communication, takes place to complete the task. 5) Learning activities are group division and assignment that challenges active students in completing tasks by looking for other information and comparing with theory.

Based on these findings learning with lesson study learning in accordance with the results of research (Histor 2018) groups can develop leadership skills, time management, empathy, communication and moderation focus. Likewise, the presentation of research results (Akerson et al. 2017) students are able to collaborate in groups and produce many ideas to be able to communicate with other teams and groups. Likewise, (Antika 2014) and (Kom and Cs 2014) Student center learning will increase activities during learning such as responsibility, participation, independence, cooperation, critical thinking, communicative and integrity of students.

Other findings obtained by researchers through observations namely seating position affect the pattern of interaction, (8) low response to a question. This shows that through the lesson study an educator will know the subject matter faced by students and through learning reflexes will impact the improvement of the learning process to improve the quality of student learning. This is in accordance with (Lomibao 2016) (Histor 2018) and his opinion (Hurd, Jacqueline; Licciardo-Muso 2005).

Student learning outcomes with the use of lesson study are able to achieve $90 \%$ classical completeness with an average value of 88.7. This shows that the application of SCL through lesson study is effective in learning outcomes. This is in accordance with his research (Achda 2013) (Dewi 2013) that the student-centered influences student learning outcomes.

\section{CONCLUSIONS AND SUGGESTIONS}

Based on the results of the research and the discussion described earlier, it can be concluded as follows.

1. Learning with the student-centered learning through lesson study can have the effect of defending leadership skills, time management, and empathy, communication focus, active and contextual.

2. Learning with the student-centered learning approach through lesson study can find out the best way to optimize the quality of student learning.

3. Learning with the student-centered learning through lesson study was influence learning outcomes.

The suggestions that researchers need based on the results of the study areas educators must always improve the learning quality of students through continuous evaluation.

\section{REFERENCES}

Achda, M. M. D. (2013). Efektivitas Penggunaan Metode Pembelajaran Students Centered Learning ( Scl) Berbasis Handout Pada Kompetensi Dasar Terbadap Hasil Belajar Ips Siswa Kelas Viii Smp N 1 Ungaran. Universitas Negeri Semara. Universitas Negeri Semarang.

Afiatin, T. (2005). "Pembelajaran Berbasis Student Centered Learning". Disampaikan dalam Lokakarya SCL ProgramHibah Kompetensi A-2 Fakultas Ilmu Sosial dan Ilmu Politik Universitas Indonesia pada tanggal 18-19 Agustus 2005.

Akerson, V. L; Khemmawadee, Meredith A Park Rogers, Ingrid Carter, and Enrique Galindo. (2017). Exploring the Use of Lesson Study to Develop Elementary Preservice Teachers. Pedagogical Content Knowledge for Teaching Nature of Science, 293-312. https://doi.org/10.1007/s10763-015-9690-x.

Antika, R. R. (2014). Proses Pembelajaran Berbasis Student Centered Learning (Studi Deskriptif Di Sekolab Menengah Pertama Islam Baitul Trzah, Nganjuk), no. 1: 251-63. 
Dewi, C K. (2013). Efektivitas Penggunaan Metode Pembelajaran SCl Berbasis Jejaring Sosial Geschool Dalam Pembelajaran TIK Untuke Meningkatkan Hasil Belajar Siswa Kelas XI SMA Negeri 1 Depok. Pregraduates Thesis.

Histor, A. (2018). “The Effects of the Research Lesson Study ( RLS ) Model on Teachers' Professional Development *" 10 (3): 215-29.

Hurd, J; Licciardo-Muso, L. (2005). "Lesson Study: Teacher-Led Professional Development in Literacy Instruction," no. May.

Jacobsen, D. A.; Paul, E; \& Donald, K. (2009). Methods For Teaching: Metode-metode Pengajaran Meningkatkan Belajar Siswa TK-SMA. Yogyakarta: Pustaka Pelajar

Kom, T. W. S, and M Cs. (2014). "Penerapan Metode SCL ( Student Centered Learning ) Berbasis Classroom Blogging Untuk Meningkatkan Keaktifan Belajar Siswa ( Studi Kasus Pada Mata Pelajaran TIK Kelas IX SMP Kristen Satya Wacana Salatiga) Penerapan Metode SCL ( Student Centered Learning ) Berbasis Classroom Blogging Untuk Meningkatkan Keaktifan Belajar Siswa ( Studi Kasus Pada Mata Pelajaran TIK Kelas IX SMP Kristen Satya Wacana Salatiga ).”

Lomibao, L. S. (2016). "Enhancing Mathematics Teachers' Quality through Lesson Study." SpringerPlus. Springer International Publishing. https://doi.org/10.1186/s40064-016-3215-0.

Nuha, M. A. (2018). "Mathematical Creative Process Wallas Model in Students Problem Posing with Lesson Study Approach" 11 (2): 527-38.

Priyatmojo, A (et al). (2010). Buku Panduan Pelaksanaan Students Centered Learning (SCL) dan Students Teacher Aesthethic Role-Sharing (STAR). Pusat Pengembangan Pendidikan: Universitas Gadjah Mada

TIM Sibbalad. (2009). "The Relationship Between Lesson Study and Selft-Efficacy.”

Triyono, M. B. (2011). Student Centered Learning: Aplikasi di Laboratorium/ Bengkel. Pelatihan SCL Politeknik Negeri Bali di Denpasar-Juni 2011

Undang-Undang Republik Indonesia nomor 20 Tahun 2003 tentang Sistem Pendidikan 